\title{
Comparison of Coping Strategies and Psychological Hardiness in Matriarchs and Married Mothers under the Auspices of Supportive Institutions
}

\author{
Mahdieh Ghale Noee ${ }^{1}$, Ferasat Ahmadi², Jamileh Mohtashami ${ }^{3}$, Elham Shaarbaf Eidgahi ${ }^{4}$ Ghazal Mohamadi ${ }^{5}$
}

${ }_{1}^{1}$ Psychiatric Nursing Department, School of Nursing \& Midwifery, Shahid Beheshti University of Medical Sciences, Tehran, Iran. ${ }^{2}$ Student of Psychiatric Nursing, Student Research Committee, School of Nursing and Midwifery, Shahid Beheshti University of Medical Sciences, Tehran, Iran. ${ }^{3}$ Associate Professor, Psychiatric Nursing Department, School of Nursing and Midwifery, Shahid Beheshti University of Medical Sciences, Tehran, Iran. ${ }^{4}$ PhD Student of Biostatistics, Department of Biostatistics, Faculty of Paramedical Sciences, Shahid Beheshti University of Medical Science, Tehran, Iran.

${ }^{5}$ Student of Research Committee, Kurdistan University of Medical Sciences, Sanandaj, Iran

\section{ABSTRACT}

\section{BACKGROUND}

Matriarchs are considered as high-risk populations in any society. Understanding the dimensions of psychological hardiness and coping strategies used by individuals can help to better manage mothers' behaviours. The current study aimed at comparing the coping strategies and psychological hardiness between matriarchs and married mothers.

\section{METHODS}

The current descriptive-comparative study was conducted on 208 married mothers and matriarchs under the auspices of supportive institutions in Sanandaj City, Iran, from 2017 to 2018. The mothers who participated in this study were selected through simple random sampling. Data was collected by the Billings \& Moos coping response inventory and the Lang \& Goulet psychological hardiness scale. Data was analysed with SPSS Version 25.

\section{RESULTS}

The results of the current study showed that matriarchs and married mothers had no difference in problem-oriented and emotion-oriented coping strategies ( $p>0.05)$. There was a significant difference between psychological hardiness and its two components, control and commitment $(\mathrm{p}<0.05)$.

\section{CONCLUSIONS}

In general, matriarchs have higher degrees of hardiness than ordinary mothers. This suggests that the occurred situation and retaining the responsibility of children increase the psychological hardiness in matriarchs. In addition, the role of being a mother is more important than the wifehood role or re-marriage.

\section{KEY WORDS}

Coping Strategies, Psychological Hardiness, Matriarchs

\author{
Corresponding Author: \\ Ferasat Ahmadi, \\ Student of Psychiatric Nursing, \\ Student Research Committee, \\ School of Nursing and Midwifery, \\ Shahid Beheshti University of Medical \\ Sciences, Tehran, Iran. \\ E-mail: hadismast@gmail.com
}

DOI: $10.14260 /$ jemds/2019/693

Financial or Other Competing Interests: None.

How to Cite This Article:

Noee MG, Ahmadi F, Mohtashami J, et al. Comparison of coping strategies and psychological hardiness in matriarchs and married mothers under the auspices of supportive institutions. J. Evolution Med. Dent. Sci. 2019;8(43):3195-3200, DOI: $10.14260 /$ jemds/2019/693

Submission 21-08-2019,

Peer Review 09-10-2019,

Acceptance 15-10-2019,

Published 28-10-2019. 


\section{BACKGROUND}

Motherhood is a challenging role even for successful and educated women benefitting from a supportive system including husband and parents.(1) Motherhood, especially in single women, is associated with higher vulnerability to a variety of risks, ranging from economic problems to poor mental functioning. $(2,3)$ Matriarchs bear higher degrees of tensions in playing parenting roles compared to married women, and often experience stress and conflict between family and work.(4) The matriarchs should play the role of both father and mother, in the absence of the father; upbringing, supporting, clothing, feeding, housing, etc., all should be provided by only the mother, without the assistance of father.(5) Low-income mothers eagerly play their parenting role without receiving a larger social support for childrearing and spend their own physical and emotional health under such circumstances.(6) Families headed by matriarchs are much poorer than ordinary families.(7-12) Matriarchs and their children are among the vulnerable groups of the society. $(11,13,14)$ The matriarchy includes a wide range of experiences in not being accepted in the family and the society.(15) Mothers spend a lot of energy, not only on their parenting roles, but also for the larger problems threatening their family lives.(16) It refers to behaviours protecting people from mental damages in terms of experiencing social problems.(17) Coping is defined as the cognitive and behavioural efforts made to master, tolerate, or reduce external and internal demands and conflicts among them. Such coping efforts serve two main functions: an appraisal of harm/loss, threat, or challenge stimulates coping efforts that change the person-environment relationship by altering the relationship itself(problem-focused coping) and/or by regulating emotional distress (Emotion-focused coping).(18) The theory of coping traditionally focuses on the management of distress and problems.(19) Psychological hardiness leads to a reasonable strategic use and the reduction of the risk of using inefficient strategies.(20) Psychological hardiness is an aspect of personality traits that acts as a source of resistance in the face of stressful life events.(21) Personality hardiness refers to commitment, control, and challenge. $(21,22)$ In fact, feeling of control over life events is the tendency toward facing challenges and beliefs in the capability of recognizing personal abilities.(23) Accidents and stressful events of life are often inevitable and mentally perceived.(24) Stressful events increase pressure, but reduce its hardiness.(25) Some previous studies indicated that single mothers had a higher level of negative coping strategies than the married ones.(26) the higher economic strain of custodial mothers contributed to impaired role-coping strategies and loss of parental control, which ultimately interfered with parenting.(27) In women, hardiness may be more related to mental health.(28) Women with higher degrees of optimism and hardiness are more likely to use positive, spiritual, and planning coping strategies. $(29,30)$ Some studies showed that despite the low level of support, increased pressures of life, and changes in the lives, there is no difference between single mothers and married ones in coping with difficulties.(31) Single mothers can cope with stressors similar to married ones.(32) There is no difference in psychological hardiness between single, divorced, and married mothers.(33) All healthcare and supportive groups should develop their insights on the unique needs and problems of the poor families and the families headed by matriarchs as well as their weaknesses and strengths. Nursing studies are required in this field; in addition, the process developing this knowledge is important. In the current study, matriarchs and married mothers were compared in terms of coping strategies and psychological hardiness under similar economic-cultural situations.

\section{METHODS}

The current descriptive-comparative study was conducted on 208 matriarchs and married mothers under the auspices of the Imam Khomeini Relief Committee and the Welfare Organization in Sanandaj, from 2017 to 2018. Mothers were allocated into two groups of 104 subjects using simple random selection method. To collect the data, the researcher referred to the Imam Khomeini Relief Committee and Welfare Organization in Sanandaj after obtaining the ethical code from the Ethics Committee of Shahid Beheshti University of Medical Sciences as well as the permission from the ViceChancellor of Education and Research of the Faculty of Nursing and Midwifery. After reviewing the introduction letter by the authorities and security officials of the organizations, the permission was issued by the Kurdistan Province offices of the Imam Khomeini Relief Committee and the Welfare Organization to be submitted to the districts 1 and 2 of the Imam Khomeini Relief Committee offices and the local office of Welfare Organization in order to provide access to Social Services Statistics under the supervision of social workers and a physical space was given to the researcher to complete the questionnaires via interviewing the participants. A demographic characteristics questionnaire, the Billings \& Moos coping response inventory (CRI) as well as the Lang \& Goulet psychological hardiness scale (LGHS) was employed to gather data of mothers. First, demographic characteristics of mothers were collected in two matched groups. Then, the Billings \& Moos CRI, developed in 1984, consisting of 32 items was used. The CRI consists of five subsamples including problem solving, cognitive assessment, excitement, physicalization and social support, which are categorized in two categories of Problem-oriented coping and emotional-oriented coping.

Problem solving, cognitive assessment, and social support through counseling experts are in the realm of problemoriented coping strategies, and emotion avoidance, somatization, and seeking social support from friends, family, and non-experts for confabulation constitute emotionoriented coping strategies. ${ }^{(34,35)}$ According to Billings and Moos, the validity of CRI was 0.62.(35) In Iran, the content validity of CRI was 0.88 (36) In the study by Chavoshifar and Rasoulzadeh Tabatabai, the validity of CRI was 0.89.(37) In this study, an Interclass Correlation Coefficient test was used to determine the reliability of which was 0.94 . Third, the Lang \& Goulet psychological hardiness scale (LGHS), developed by Lang and Goulet was used. LGHS is a self-report scale with 45 items. ${ }^{(38)}$ Roshan and Shakeri translated the questionnaire into Persian and based on the results of their study, reduced the items of the scale to 42 in three subscales of control (16 items), commitment (15 items), and challenging 
(11 items). The validity of the LGHS was confirmed using the factor analysis, structural validity, convergent validity, and differential validity. The content validity of the scale was calculated through construct validity $(r=0.64 ; \mathrm{p}=0.000)$. The differential validity was $r=0.47$. Convergent validity in the subscale of control was $r=0.91$, commitment $r=0.86$, and challenging $r=0.70 .{ }^{(39)}$ In the current study, the interclass correlation coefficient was used to determine the reliability of the scale that was 0.92 . The index was above 0.8 , which indicated the desired degree of stability. Collected data were analyzed with SPSS version 25. Descriptive statistics (Frequency, mean, and standard deviation) were used to express the data, and to explain the data and compare the mean of the two groups, in case of the normality of the data distribution independent t-test was employed and in case of non-normality, the non-parametric test- $\mathrm{i}$ e, the MannWhitney- was used. The level of significance was $<0.05$.

\section{RESULTS}

The mean age of the matriarch and the ordinary mother groups was $41.11 \pm 11.24$ and $39.35 \pm 10.30$ years, respectively. In the group of married mothers, all the subjects (100.0\%) lived with their spouses and in the matriarch group, majority of the subjects (53.8\%) were divorced ones followed by widows $(30.8 \%)$. All participating matriarchs and married mothers were Muslim. In addition, majority of matriarchs (54.8\%) and married mothers (52.9\%) had elementary education. Also, $97.1 \%$ of matriarchs and $86.5 \%$ of the married mothers had high school diploma or uncompleted high school education.

Based on the Mann-Whitney test, the mean scores of problem-oriented coping were similar in the two groups of mothers. The significance level was $p<0.05$ and $p=0.099$ in the problem-oriented coping, which indicated no significant difference between the matriarch and married mother groups in terms of the problem-oriented coping strategy (Table 1).

According to Levin's test of equality of variance, $p=0.798$ for the emotion-focused coping, which indicated the equality of variance between the groups and based on independent ttest, there was no significant difference between the groups $(\mathrm{p}=0.891$ ); according to the mean difference of 0.183 , there was no significant difference between the groups in terms of emotion- oriented coping strategies, which showed that matriarch and married mother groups had no difference in emotion-oriented coping strategy (Table 2).

Matriarchs and married mothers had significant difference in commitment components of the psychological hardiness. According to differences in the mean and total scores, matriarchs had more commitment to life compared to the married mothers. Matriarchs and married mothers had no significant difference in challenging subscale. According to significance level of the study $(\mathrm{p}<0.05)$, and that of the control component $(\mathrm{p}=0.055)$, no significant difference was observed between matriarchs and married mothers in psychological hardiness in terms of the challenging subscale (Table 3).
In the control component, based on Levin's test of equality of variance in the two groups, $p=0.055$, the same variance was observed in the two groups and therefore, based on the results of independent t-test $(p=0.027)$ matriarchs had more control over their family lives compared to the married mothers. In the Psychological Hardiness, based on the results of independent $t$-test $(p=0.006)$, there was a significant difference between the two study groups. matriarchs had more Psychological Hardiness in compared to the married mothers (Table 4).

\begin{tabular}{|c|c|c|c|c|c|}
\hline Group & \multicolumn{2}{|c|}{ Matriarch } & \multicolumn{2}{|c|}{ Married Mother } & \multirow[b]{2}{*}{$\mathbf{p}$} \\
\hline Subscale & $\begin{array}{l}\text { Mean } \\
\text { Score }\end{array}$ & $\begin{array}{l}\text { Total } \\
\text { Score }\end{array}$ & $\begin{array}{l}\text { Mean } \\
\text { Score }\end{array}$ & $\begin{array}{l}\text { Total } \\
\text { Score }\end{array}$ & \\
\hline $\begin{array}{l}\text { Problem-oriented } \\
\text { coping strategy }\end{array}$ & 111.36 & 10155.00 & 97.64 & 11581.00 & 0.099 \\
\hline
\end{tabular}

Table 1. Results of the Mann-Whitney Test for Problem-Oriented Coping Analysis in Matriarchs and Married Mothers Under the Auspices of the Imam Khomeini Relief Committee and the Welfare Organization in Sanandaj City

\begin{tabular}{|c|c|c|c|c|}
\hline Test & \multicolumn{2}{|c|}{ Levi's Test } & \multicolumn{2}{c|}{ Independent t-Test } \\
\hline Coping Strategy & $\mathbf{F}$ & $\mathbf{p}$ & Mean Difference & $\mathbf{p}$ \\
\hline Emotion-focused coping strategy & 0.066 & 0.798 & 0.183 & 0.891 \\
\hline
\end{tabular}

Table 2. The Results of Independent T-Test for Emotion-Focused Coping Analysis in Matriarchs and Married Mothers under the Auspices of the Imam Khomeini Relief Committee and the Welfare Organization in Sanandaj City

\begin{tabular}{|c|c|c|c|c|c|}
\hline \multirow{2}{*}{ Gubscale } & \multicolumn{2}{|c|}{ Matriarch } & \multicolumn{2}{|c|}{ Ordinary mother } & \multirow{2}{*}{ p } \\
\cline { 2 - 5 } & $\begin{array}{c}\text { Mean } \\
\text { Score }\end{array}$ & $\begin{array}{c}\text { Total } \\
\text { Score }\end{array}$ & $\begin{array}{c}\text { Mean } \\
\text { Score }\end{array}$ & $\begin{array}{c}\text { Total } \\
\text { Score }\end{array}$ & \\
\hline Commitment & 115.49 & 12010.50 & 93.51 & 9725.50 & 0.008 \\
\hline Challenging & 112.65 & 11715.50 & 96.35 & 10020.50 & 0.050 \\
\hline
\end{tabular}

Table 3. The Results of the Mann-Whitney Test to Compare Commitment and Challenging Components between Matriarchs and Married Mothers Under the Auspices of the Imam Khomeini Relief Committee and the Welfare Organization in Sanandaj City

\begin{tabular}{|c|c|c|c|c|}
\hline \multirow{2}{*}{ Gubscale } & \multicolumn{2}{|c|}{ Levi's Test } & \multicolumn{2}{c|}{ Independent t-Test } \\
\cline { 2 - 5 } & $\mathbf{F}$ & $\mathbf{p}$ & Mean Difference & $\mathbf{p}$ \\
\hline Control & 3.739 & 0.55 & 2.586 & 0.027 \\
\hline Psychological Hardiness & 4.344 & 0.038 & 5.365 & 0.006 \\
\hline Table 4. Results of Independent T-Test in the Control Component between \\
Matriarchs and Married Mothers under the Auspices of the Imam Khomeini \\
Relief Committee and the Welfare Organization in Sanandaj City \\
\hline
\end{tabular}

\section{DISCUSSION}

In the current study, the coping strategy was investigated in its two main dimensions as problem-oriented and emotionoriented coping strategies. There was no significant difference between the matriarchs and married mothers in terms of both problem-oriented and emotion-oriented coping strategies that was in line with the findings of Weinraub \& Wolf, Holloway \& Machida, Propst et al., Williams, and Arditti \& Maddenderdich. The conceptual understanding of divorced mothers of coping leads to the use of problem-oriented coping strategy.(40) Use of active coping strategies with a sense of control over childbearing practices alongside a potent parenting was significantly higher in divorced mothers.(41) Despite lower levels of social support, increased pressure of life, and the changes in the life, single mothers were similar to married mothers in coping with difficulties.(31) Single mothers are potent to cope with stressors similar to their married counterparts.(32) Children are the source of emotional support and the concept of the continuity of the goals of single mothers in terms of dealing with parental tasks. ${ }^{42)}$ 
Nevertheless, findings of the current study were inconsistent with those of Hilton \& Desrochers and Sperlich \& Maina. Single mothers showed a higher level of negative coping strategies than the married ones.(26) the higher economic strain of custodial mothers contributed to impaired role-coping strategies and loss of parental control, which ultimately interfered with parenting.(27)

Psychological hardiness was investigated in three dimensions of control, commitment, and challenging, and the results showed a significant difference between matriarchs and married mothers in the control and commitment dimensions. Matriarchs had higher levels of control and commitment than married mothers.

Findings of the current study were in line with those of the studies by Hamid, Ashoori, Haidarabadi, and Smith reporting that women with higher hardiness could appraise stressful events more positively and manageably than the ones with lower hardiness.(43) When mothers learn psychological hardiness, they can assess stressful life events positively and more manageably.(44) Matriarchs, due to their feelings with their children, endure the pressures of life and are often responsible.(45) Parents with higher hardiness have higher sense of commitment and share in parental roles.(46)

On the other hand, the findings of the current study were inconsistent with those of Schneewind \& Pfeiffer as well as Bahmani et al. Single mothers and mothers in weak marriages have lower levels of commitment than their counterparts in more strong marriages.(47) Spirituality of mothers with disabled children makes them more likely to manage their lives, more active to deal with events, and more committed.(48) In the current study, there was no significant difference in religious beliefs between the two groups.

Matriarchs and married mothers did not differ in the challenging components of psychological hardiness. This finding was consistent with those of Gucciardi, Celasun \& Stewart, Smith, and Luthar \& Ciciolla. Motherhood is a challenging task even for successful and educated women benefitting from a supportive system including husband and parents.(1) Single mothers face more challenges than the ordinary ones.(49) When parents face parental challenges, hardiness may be a stress reliever.(46) Matriarchs faced a greater challenge in life, but they were similar to married mothers in challenging trait, which could be due to a higher psychological hardiness in matriarchs.

In the current study, the total psychological hardiness was compared and evaluated in matriarchs and married mothers. In psychological hardiness, matriarchs and married mothers showed differences. Matriarchs had more hardiness than married mothers. The findings of the current study were in line with those of Robitschek \& Kashubeck, DelGrande, Ben-Zur, Duvdevany \& Lury, Davoudimoghaddam et al., and Tomassetti-Long. For women, hardiness appeared to mediate partially the relation of family functioning to well-being.(50) Mothers in the non-depressed group had higher hardiness than their depressed counterparts. (51)

Psychological hardiness and social support are strongly dependent on the mental health of mothers. (52) Hardiness training as an effective factor in stress management can improve the personal and social compatibility in matriarchs. (53) Psychological hardiness has a positive effect on parental stress. ${ }^{(54)}$ The results of the current study were in agreement with those of Smith Cohen \& Dekel, Schmied \&
Lawler, Subramanian \& Nithyanandan, Sarani et al. Higher hardiness is associated with positive parental practices and low hardiness with negative parenting practices. ${ }^{(46)}$ Hardiness in women may be more related to mental health.(28) Women with optimism and higher hardiness are more likely to use positive, spiritual, and planning coping strategies. $(29,30)$ The findings of the current study were inconsistent with those of Schmied \& Lawler, Gill \& Harris, and Segal-Engelchin. People receiving more social support express higher hardiness.(55) Hardiness is significantly correlated with age, level of education, and marital status. Older married people with higher levels of education have higher hardiness.(28) There is no difference in psychological hardiness between single, divorced, and married mothers.(33)

In the current study, the hardiness of matriarchs was higher than that of married mothers, which can be due to the lack of independence and dependence of married mothers on their spouses or fear of divorce and stigma of the community forcing them to continue their lives with such emotional distance and the challenging relationship with their spouses. The most important limitation of the current study was the homogeneity of the study subjects in terms of race and religion, which limited the generalization of the results. In addition, the instruments were self-reporting.

\section{CONCLUSIONS}

The results of the current study showed that matriarchs and married mothers had no significant differences in terms of problem-oriented and emotion-focused coping strategies. In total, the matriarchs had higher hardiness than married mothers, which indicated that accepting the childbearing responsibilities intensified hardiness in matriarchs. In addition, the current study results showed that the motherhood role was more important than the womanhood role or re-marriage. According to the results of the current study, future studies are suggested on populations of diverse cultural and social backgrounds.

\section{REFERENCES}

[1] Luthar SS, Ciciolla L. Who mothers mommy? Factors that contribute to mothers' well-being. Developmental Psychology 2015;51(12):1812-23.

[2] Taylor ZE, Conger RD. Promoting strengths and resilience in single-mother families. Child Development 2017;88(2):350-8.

[3] Dziak E, Janzen BL, Muhajarine N. Inequalities in the psychological well-being of employed, single and partnered mothers: the role of psychosocial work quality and work-family conflict. International Journal for Equity in Health 2010;9:6.

[4] Robbins LR, McFadden JR. Single mothers: the impact of work on home and the impact of home on work. Journal of Family and Consumer Sciences Education 2003;21(1):1-10.

[5] Fluellen JL. Single mothers of young children and continuing education: Walden University 2016. 
[6] Elliott S, Powell R, Brenton J. Being a good mom: Lowincome, Black single mothers negotiate intensive mothering. Journal of Family Issues 2015;36(3):351-70.

[7] Christopher K. Welfare state regimes and mothers' poverty. Social Politics: International Studies in Gender, State \& Society 2002;9(1):60-86.

[8] Jayakody R, Chatters LM, Taylor RJ. Family support to single and married African American mothers: the provision of financial, emotional and child care assistance. Journal of Marriage and Family 1993;55(2):261-76.

[9] Lokshin M, Harris KM, Popkin BM. Single mothers in Russia: household strategies for coping with poverty. World development 2000;28(12):2183-98.

[10] Maldonado LC, Nieuwenhuis R. Family policies and single parent poverty in 18 OECD countries, 1978-2008. Community, Work \& Family 2015;18(4):395-415.

[11] Misra J, Moller S, Strader E, et al. Family policies, employment and poverty among partnered and single mothers. Research in Social Stratification and Mobility 2012;30(1):113-28.

[12] Van de Velde S, Bambra C, Van der Bracht K, et al. Keeping it in the family: the self-rated health of lone mothers in different European welfare regimes. Sociology of Health \& Illness 2014;36(8):1220-42.

[13] Berkman LF, Zheng Y, Glymour MM, et al. Mothering alone: cross-national comparisons of later-life disability and health among women who were single mothers. J Epidemiol Community Health 2015;69(9):865-72.

[14] Broussard CA, Joseph AL, Thompson M. Stressors and coping strategies used by single mothers living in poverty. Affilia 2012;27(2):190-204.

[15] Welch A, Hong RM. The vicissitudes of being a single mother in Taiwan: a mental health concern. Journal of Psychiatric and Mental Health Nursing 2013;20(10):94350.

[16] Sheppard M. Mothers' coping strategies as child and family care service applicants. British Journal of Social Work 2005;35(5):743-59.

[17] Pearlin LI, Schooler C. The structure of coping. Journal of Health and Social Behaviour 1978;19(1):2-21.

[18] Folkman S, Lazarus RS. An analysis of coping in a middleaged community sample. Journal of Health and Social Behaviour 1980;21(3):219-39.

[19] Folkman S. Positive psychological states and coping with severe stress. Social Science \& Medicine 1997;45(8):1207-21.

[20] Maddi SR. Relevance of hardiness assessment and training to the military context. Military Psychology 2007;19(1):61-70.

[21] Kobasa SC. Stressful life events, personality and health: an inquiry into hardiness. Journal of Personality and Social Psychology 1979;37(1):1-11.

[22] Kobasa SC, Maddi SR, Zola MA. Type A and hardiness. Journal of Behavioural Medicine 1983;6(1):41-51.

[23] Lang CG, Marilyn Aita M, et al. Weathering the storm of perinatal bereavement via hardiness. Death Studies 2001;25(6):497-512.

[24] Atkins R. Depression in Black single mothers: a test of a theoretical model. Western Journal of Nursing Research 2015;37(6):812-30.
[25] Maddi SR. The personality construct of hardiness: I. Effects on experiencing, coping and strain. Consulting Psychology Journal: Practice and Research 1999;51(2):83-94.

[26] Sperlich S, Maina MN. Are single mothers' higher smoking rates mediated by dysfunctional coping styles? BMC Women's Health 2014;14(1):124.

[27] Hilton JM, Desrochers S. The influence of economic strain, coping with roles and parental control on the parenting of custodial single mothers and custodial single fathers. Journal of Divorce \& Remarriage 2000;33(3-4):55-76.

[28] Schmied LA, Lawler KA. Hardiness, type A behaviour and the stress-illness relation in working women. Journal of Personality and Social Psychology 1986;51(6):1218-23.

[29] Subramanian S, Nithyanandan M. Hardiness and optimism as moderators of cognitive emotion regulation strategies in coping negative life events by adolescents. Department of Psychology, Bharathiar University, 2007;6(41):1-19.

[30] Sarani A, Azhari S, Mazlom SR, et al. The relationship between psychological hardiness and coping strategies during pregnancy. Journal of Midwifery and Reproductive Health 2015;3(3):408-17.

[31] Weinraub M, Wolf BM. Effects of stress and social supports on mother-child interactions in single-and twoparent families. Child development 1983;54(5):1297311.

[32] Williams NY. The relationship between stress, coping strategies and social support among single mothers. 2016.

[33] Segal-Engelchin D. Fear of intimacy and hardiness among single mothers by choice: A comparison to divorced and married mothers. Journal of Family Social Work 2008;11(2):95-116.

[34] Nasaji GS, Paivastegar MA, Hosinian S, et al. The effectiveness of cognitive-behavioural intervention on coping responses and cognitive strategies for women's emotions. Journal of Behavioural Sciences 2010;4(1):3543.

[35] Billings AG, Moos RH. Coping, stress and social resources among adults with unipolar depression. Journal of Personality and Social Psychology 1984;46(4):877-91.

[36] Sharbaf AHR, Pazhakhzade S. Comparison of stressors and coping strategies in students. J Psychol 2002;6(2).

[37] Chavoshifar J, Tabatabaie RK. Comparative study of stressors and coping styles in adolescents in boarding care centers and adolescents with parents. J Psychol 2000;4(2):169-84.

[38] Lang A, Goulet C, Amsel R. Lang and Goulet hardiness scale: development and testing on bereaved parents following the death of their fetus/infant. Death Studies 2003;27(10):851-80.

[39] Roshan R, Shakeri R. Evaluation of validity and reliability of scale for students' psychological hardiness. ScientificResearch Journal of Shahed University 2010;17(40):3552.

[40] Propst R, Pardington A, Ostrum R, et al. Predictors of coping in divorced single mothers. Journal of Divorce 1986;9(3):33-53. 
[41] Holloway SD, Machida S. Child-rearing effectiveness of divorced mothers: relationship to coping strategies and social support. Journal of Divorce \& Remarriage 1991;14(3-4):179-202.

[42] Arditti JA, Madden-Derdich D. No regrets - custodial mothers accounts of the difficulties and benefits of divorce. Contemporary Family Therapy 1995;17(2):22948.

[43] Ashoori J. Investigation the role of social capital, social support and psychological hardiness in predicting life quality of elderly women. 2018.

[44] Haidarabadi ZG. Effectiveness of reality therapy education to increase happiness and hardiness of mothers who have blind child. Kuwait Chapter of the Arabian Journal of Business and Management Review 2014;3(10):293-300.

[45] Hamid AA. Social change impact on female headed families in Sudanese community case study: Omdurman City: Sudan University of Science and Technology, 2014.

[46] Smith E. The role of parental self-efficacy, hardiness, parenting stress in predicting parenting behaviours. The University of Southern Mississippi, 2017.

[47] Schneewind KA. Impact of family processes on control beliefs. In: Bandura A, edr. Self-efficacy in changing societies. New York, NY, US: Cambridge University Press 1995: p. 114-148.

[48] Bahmani B, Ebrahimi M, Seyadi MS, et al. The role of spiritual attitude in child-rearing in predicting the psychological hardiness of mothers with handicapped children. Iranian Rehabilitation Journal 2015;13(2):34-7.
[49] Gucciardi E, Celasun N, Stewart DE. Single-mother families in Canada. Canadian Journal of Public Health/Revue Canadienne de Sante'e Publique 2004;95(1):70-3.

[50] Robitschek C, Kashubeck S. A structural model of parental alcoholism, family functioning and psychological health: The mediating effects of hardiness and personal growth orientation. Journal of counseling psychology. 1999;46(2):159-72.

[51] DelGrande A. Role discrepancy, maternal hardiness and depression in mothers of toddlers: a qualitative exploration. 2015.

[52] Ben-Zur H, Duvdevany I, Lury L. Associations of social support and hardiness with mental health among mothers of adult children with intellectual disability. Journal of Intellectual Disability Research. 2005;49(1):54-62.

[53] Davoudimoghaddam B, Raheb G, Hosseinzadeh S, Teymouri R. The effect of hardiness on personal and social adjustment of female-headed households. Middle East Journal of Family Medicine. 2018;7(10):236-42.

[54] Tomassetti-Long VJ. Hardiness, social support, parental stress, and posttraumatic stress symptoms in recent service members. 2014.

[55] Gill MJ, Harris SL. Hardiness and social support as predictors of psychological discomfort in mothers of children with autism. Journal of Autism And Developmental Disorders. 1991;21(4):407-16. 